\title{
Bladder dysfunction in distal autonomic neuropathy of acute onset
}

\author{
ROGER S KIRBY, CLARE J FOWLER, JOHN A GOSLING, ROGER BANNISTER \\ From the Department of Urology, the Middlesex Hospital, the National Hospital for Nervous Diseases, \\ London, and the Department of Anatomy, University of Manchester, UK
}

SUMMARY A patient with cholinergic dysautonomia and a patient with pandysautonomia have each been investigated for disturbances of bladder and urethral function. Both patients suffered from an inability to develop or sustain a detrusor contraction, while retaining normal bladder sensation. Biopsy specimens of bladder muscle stained for acetylcholinesterase revealed a significant reduction in cholinergic nerves compared with controls; however, the prominent cholinergic subepithelial plexus was strikingly preserved. These findings lend support to the view that acetylcholinesterase-containing nerves in the bladder muscle are motor fibres responsible for detrusor contraction, while those located in the subepithelium are sensory in function. Urethral sphincter electromyography revealed no abnormality of individual motor units, confirming that motor unit integrity in this muscle is dependent upon somatic rather than autonomic innervation. In the patient with pandysautonomia the proximal urethra was incompetent, while in the patient with cholinergic dysautonomia the bladder neck remained closed, as in controls. This suggests that sympathetic rather than parasympathetic efferent activity is necessary for the maintenance of proximal urethral competence.

\section{Bladder dysfunction in distal autonomic neuropathy}

Selective autonomic neuropathy of acute onset was first reported by Young et al. ${ }^{2}$ Since then 13 other cases of acute or subacute pandysautonomia have been described ${ }^{3-14}$ (table 1), with or without associated peripheral sensory, and motor nerve involvement. It is now recognised ${ }^{15}$ that a rare variant of this condition may occur, in which peripheral parasympathetic nerves alone are affected. Five cases of this disorder, which has been termed cholinergic dysautonomia, have been reported ${ }^{4}{ }^{16-19}$ (table 2). In both pandysautonomia and pure cholinergic dysautonomia of acute onset disturbances of micturition are prominent; however, there have been no previous studies concerning the nature of the vesical dysfunction that these patients suffer. The results of a detailed urodynamic, electromyographic and neurohistochemical study in two patients with distal autonomic neuropathy of acute onset are now presented and compared with results obtained in a series of age-matched controls.

Address for reprint requests: Roger S Kirby, FRCS, Department of Urology, Middlesex Hospital, London WIN 8AA, UK.

Received 5 October 1984 and in revised form 17 December 1984. Accepted 24 December 1984

\section{Patients}

Two patients with distal autonomic neuropathy were investigated and the results compared with those obtained in 10 female patients (age range $21-45 \mathrm{yrs}$ ) who had been admitted for renal or ureteric surgery and who complained of no lower urinary tract symptoms. Written informed consent was obtained in every case.

\section{Case 1 Cholinergic dysautonomia}

This female patient presented in 1969, aged 11 years, with an acute onset of abdominal pain and blurred vision. After a period of urinary frequency, she developed painful acute retention and required catheterisation. On examination the pupils were dilated, the abdomen was distended and bowel sounds were absent. At laparotomy, performed to exclude intestinal obstruction, distended loops of bowel were found, but there was no localised intra-peritoneal pathology. The paralytic ileus persisted for almost a month and removal of the catheter failed to restore normal micturition. Six weeks after the onset of the illness, $100 \mu \mathrm{g}$ of carbachol (one-fifth the usual dose) was given subcutaneously. This produced severe abdominal pain, vomiting, profuse sweating and a desire to micturate. After further physiological investigation, as reported previously (by Hopkins $e a^{4}$ ) and subsequent studies by methods described by Bannister, ${ }^{15}$ a diagnosis of pure cholinergic duysautonomia was made. Although the patient had normal sensation of bladder distension, micturition was never 
Table 1 Pandysautonomia

\begin{tabular}{|c|c|c|c|c|c|c|c|}
\hline \multirow{2}{*}{$\begin{array}{l}\text { Author } \\
\text { Appenzeller and Kornfield }\end{array}$} & \multirow{2}{*}{$\begin{array}{l}\begin{array}{c}\text { Age } \\
(y r)\end{array} \\
d^{3} 6\end{array}$} & \multirow{2}{*}{$\begin{array}{l}\text { Sex } \\
M\end{array}$} & \multicolumn{2}{|c|}{ Cholinergic/Adrenergic Site of neural Injury } & \multirow[t]{2}{*}{$\begin{array}{l}\text { Other neurological } \\
\text { deficit }\end{array}$} & \multicolumn{2}{|c|}{ Urological problem Recovery/duration } \\
\hline & & & Both & Post-ganglionic & & $\begin{array}{l}\text { Retention. Voids } \\
\text { by straining }\end{array}$ & Complete (16 yr) \\
\hline Hopkins et al (Case 1) & 28 & F & Both & Post-ganglionic & - & $\begin{array}{l}\text { No urological } \\
\text { history recorded }\end{array}$ & Complete (4 mon) \\
\hline Yahr \& Frontera ${ }^{5}$ & 13 & $\mathrm{~F}$ & Both & Post-ganglionic & Decreased reflexes & $\begin{array}{l}\text { No urological } \\
\text { history recorded }\end{array}$ & Good \\
\hline Okada $e t a l^{6}$ & 43 & $\mathbf{M}$ & Both & Post-ganglionic & Decreased reflexes & $\begin{array}{l}\text { "Hypotonic" } \\
\text { bladder }\end{array}$ & Moderate (31 mon) \\
\hline Ibid. (Case 2) & 37 & $\mathbf{M}$ & Both & Pre-ganglionic & - & Impotence & Complete (1 yr) \\
\hline Wischer et al. & 47 & $\mathrm{~F}$ & Both & Post-ganglionic & - & $\begin{array}{l}\text { No urological } \\
\text { history recorded }\end{array}$ & Partial (14 mon) \\
\hline Young et al. ${ }^{2}$ & 49 & $\mathbf{M}$ & Both & Post-ganglionic & -- & Areflexic bladder & Complete ( 17 mon) \\
\hline Yee et al. ${ }^{\mathrm{x}}$ & 39 & $\mathbf{M}$ & Both & Post-ganglionic & - & $\begin{array}{c}\text { "Incomplete" } \\
\text { micturition }\end{array}$ & Partial (6 yr) \\
\hline Low et al. ${ }^{y}$ & 46 & $\mathbf{F}$ & Both & Post-ganglionic & $\begin{array}{l}\text { Impaired thermal } \\
\text { sensation }\end{array}$ & Retention & Poor ( 5 yr) \\
\hline Ibid (Case 2) & 74 & $\mathbf{F}$ & Both & Post-ganglionic & - & Retention & Not recorded \\
\hline Estanol-Vidal et al. ${ }^{10}$ & 20 & $\mathrm{~F}$ & Both & Post-ganglionic & Decreased reflexes & Retention & Poor (1 yr) \\
\hline Goulon et al." & 40 & $\mathbf{M}$ & Both & Post-ganglionic & $\begin{array}{l}\text { Opthalmoplegia } \\
\text { Ataxia (L) Babinski } \\
\text { sign }\end{array}$ & Retention of urine & Good ( 3 mon) \\
\hline Colan et al. ${ }^{12}$ & 9 & $\mathbf{M}$ & Both & Post-ganglionic & Sensory loss & Retention of urine & $\begin{array}{l}\text { Autonomic: Good; } \\
\text { Sensory: Poor }\end{array}$ \\
\hline Fagius et al. ${ }^{13}$ & 31 & $\mathbf{M}$ & Both & Post-ganglionic & Sensory loss & Retention of urine & Poor (45 mon) \\
\hline Edelman et al. ${ }^{14}$ & 46 & $F$ & Both & Post-ganglionic & $\begin{array}{l}\text { Sensory + Motor } \\
\text { Impairment }\end{array}$ & Retention of urine & Fair ( 5 mon) \\
\hline
\end{tabular}

Table 2 Cholinergic dysautonmia

\begin{tabular}{|c|c|c|c|c|c|c|}
\hline - Author & Age & Sex & Cholinergic/Adrenergi & Site of neural injury & $\begin{array}{l}\text { Other neurological } \\
\text { deficit }\end{array}$ & Urological problemRecovery/duration \\
\hline $\begin{array}{l}\text { Thomaschevsky et al. }{ }^{16} \\
\text { Hopkins et al. }{ }^{4} \text { (Case 2) } \\
\text { Anderson } \text { et al. }{ }^{17} \\
\text { Harik et al. }{ }^{18} \\
\text { Hopkins } \text { et al. }{ }^{14}\end{array}$ & $\begin{array}{r}6 \\
11 \\
19 \\
9 \\
11\end{array}$ & $\begin{array}{l}F \\
F \\
F \\
M \\
M\end{array}$ & $\begin{array}{l}\text { Cholinergic } \\
\text { Cholinergic } \\
\text { Cholinergic } \\
\text { Cholinergic } \\
\text { Cholinergic } \\
\text { ? some adrenergic }\end{array}$ & $\begin{array}{l}\text { Post-ganglionic } \\
\text { Post-ganglionic } \\
\text { Post-ganglionic } \\
\text { Post-ganglionic } \\
\text { Post-ganglionic }\end{array}$ & $\begin{array}{l}- \\
- \\
-\end{array}$ & $\begin{array}{l}\text { Retention of urine Moderate (2 yr) } \\
\text { Retention of urine None (16 yr) } \\
\text { Retention of urine Incomplete }(2 \mathrm{yr}) \\
\text { Retention of urine Moderate }(18 \mathrm{yr}) \\
\text { Frequency of } \\
\quad \text { micturition }\end{array}$ \\
\hline
\end{tabular}

re-established and could only be achieved by suprapubic manual compression (Credé manoeuvre).

The patient had now been followed up for 15 years and during this time her clinical condition has remained static. She is only able to empty her bladder by use of the Credé manoeuvre, and this has resulted in pressure marks on the lower abdomen.

\section{Case 2 Pandysautonomia}

The female patient presented in 1980 , aged 52 years, with a subacute onset of difficulty with micturition, culminating in urinary retention. She also complained of an excessively dry mouth, severe constipation, and a sensation of dizziness on standing. On examination, both pupils were dilated, there was a total absence of sweating and the blood pressure fell from $160 / 80 \mathrm{~mm} \mathrm{Hg}$ in the supine position to $130 / 60$ on standing. Detailed physiological tests of autonomic function were undertaken according to the methods described by Bannister ${ }^{15}$ and a diagnosis of pandysautonomia of subacute onset was made. Urinary retention persisted after a prolonged period of urethral catheterisation, and the patient was therefore taught intermittent self-catheterisation. She has continued to practise this four to six times per day, for the past four years. Although she is able to perceive when her bladder is full, she is quite unable to void. At the time of the present investigation she was receiving no medication.

\section{Methods}

Urodynamic assessment was carried out by cystometry at a filling rate of $100 \mathrm{ml} / \mathrm{s}$ with simultaneous radiography of the bladder. ${ }^{20}$ In addition, the intravesical pressure response to $100 \mu \mathrm{g}$ of carbachol was assessed, after the bladder had been filled to a volume of $100 \mathrm{ml}$ with saline; a pressure rise of more than $20 \mathrm{cms}$ of water is taken to indicate denervation supersensitivity. ${ }^{21}$ A coaxial needle was inserted percutaneously into the striated muscle of the urethral sphincter and 10 individual motor units were isolated and their amplitude and duration measured from film. ${ }^{22}$ At cystoscopy bladder muscle biopsies were taken; the tissue was rapidly frozen in liquid nitrogen and subsequently processed for both acetylcholinesterase ${ }^{23}$ and tissue catecholamines. ${ }^{24}$ The density of enzyme-positive nerves was assessed using a point-counting technique. An eye-piece graticule with a grid divided into $1 \mathrm{~mm}$ squares was used. At each point of intersection the underlying tissue (that is smooth muscle cell or nerve) was noted. Different areas of tissue were examined, far enough apart to preclude counting any point twice. A minimum of 500 and 
Table 3

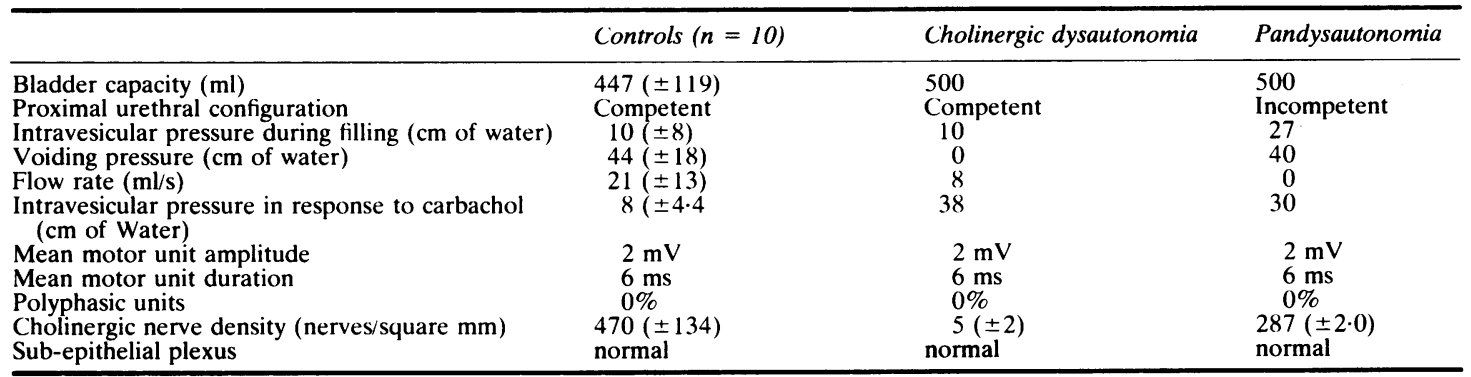

a maximum of 2000 points were counted in every case, and a mean value for the density of innervation per square $\mathrm{mm}$ was calculated for each patient.

\section{Results (Summarised in Table 3)}

Both the patient with cholinergic dysautonomia (Case 1) and the patient with pandysautonomia (Case 2) appeared to have normal sensation of bladder filling. The bladder capacity in both cases was $500 \mathrm{ml}$, a value not significantly different from the mean value found in controls $(447 \mathrm{mls} \pm$ SD 119). During filling, the proximal urethra appeared competent in Case 1, as in controls; but in the patient with pandysautonomia, the bladder neck was widely dilated. The mean intravesicular pressure rise in response to filling in the control group was $10 \mathrm{~cm}$ of water $( \pm 8 \cdot 0)$, and in no control subject did this exceed $15 \mathrm{~cm}$ of water. In the patient with pure cholinergic dysautonomia, intravesicular pressure rose to $10 \mathrm{~cm}$ during filling, while in the patient with pandysautonomia, there was a pressure rise to $27 \mathrm{~cm}$ of water.

On request to void, all the control patients were able to comply, achieving a mean intravesicular pressure of $44 \mathrm{~cm}$ of water $( \pm 18)$ and a mean flow rate of $21 \mathrm{ml} / \mathrm{s}( \pm 13)$. By contrast, the patient with cholinergic dysautonomia was unable to generate any measurable detrusor contraction, and voided by means of the Credé manoeuvre, leaving a residual volume of only $50 \mathrm{ml}$. In the patient with pandysautonomia an intravesicular pressure rise to $40 \mathrm{~cm}$ of water was recorded, but she was unable to void at all.

None of the control patients responded to subcutaneous carbachol with an intravesicular pressure rise of more than $15 \mathrm{~cm}$ of water. By contrast, both the patient with cholinergic dysautonomia and the patient with pandysautonomia exhibited supersensitive response to this drug, with intravesical pressure rises of $38 \mathrm{~cm}$ and $30 \mathrm{~cm}$ of water respectively. In association with the rise of intravesicular pressure, both patients experienced a marked desire to void, as well as a marked meiosis, profuse salivation and sweating, together with severe abdominal colic.

Individual motor units isolated from the striated muscle of the urethral sphincter of both patients with dysautonomia were within the normal range of measured range of amplitude and duration and no units were polyphasic. ${ }^{22}$

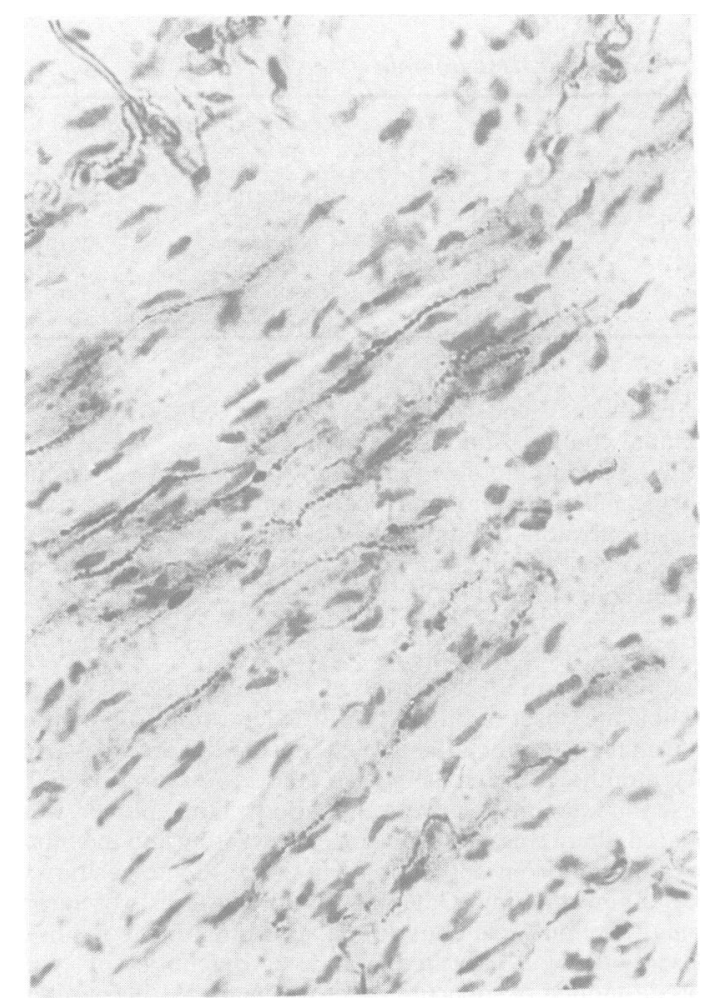

Fig. 1 Bladder muscle biopsy specimen from a female control patient, aged 35 yrs, processed to demonstrate tissue cholinesterases. Note the rich plexus of darkly staining cholinergic nerves distributed among the smooth muscle bundles. $(\times 50)$. 


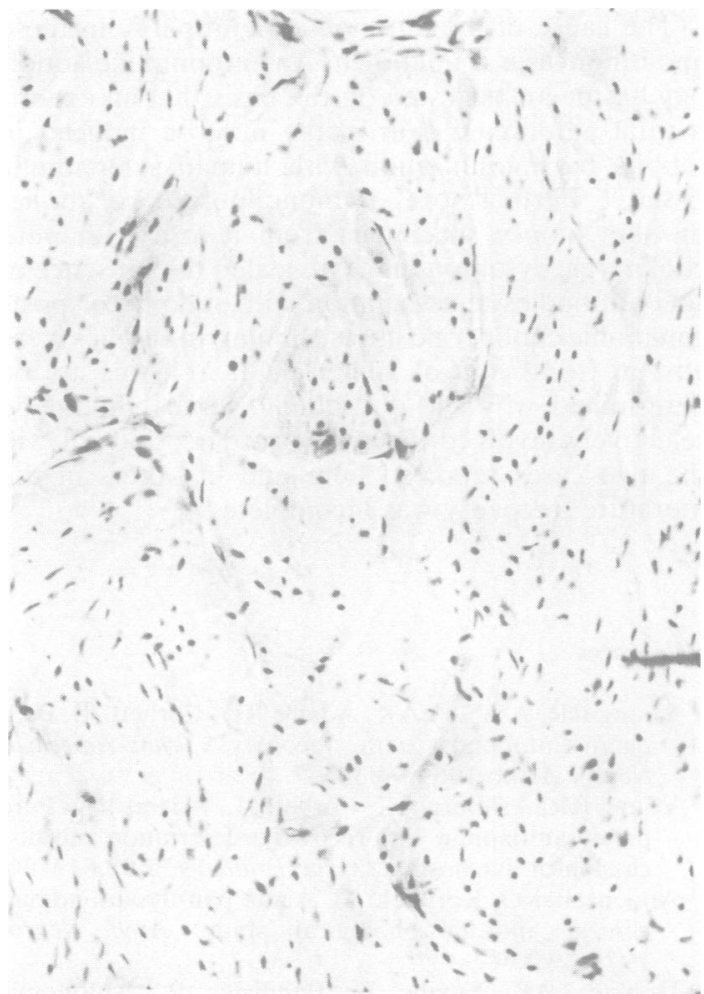

Fig. 2 Bladder muscle biopsy from the patient with cholinergic dysautonomia (case 1). There is a striking absence of acetylcholinesterase-positive nerves among the smooth muscle bundles $(\times 50)$.

In 10 control patients, bladder muscle biopsy specimens processed for tissue acetylcholinesterases revealed the presence of numerous enzyme-positive nerves in the muscularis (mean density $=470$ nerves/square $\mathrm{mm}( \pm 134)$ (fig 1). There was, in addition, a rich plexus of acetylcholinesterasepositive nerves present in the lamina propria, adjacent to the epithelium. By contrast, in the patient with cholinergic dysautonomia, the bladder muscularis was almost devoid of enzyme-containing nerves (density $=5$ nerves/square $\mathrm{mm}( \pm 2 \cdot 0)$ (fig 2 ), while that of the patient with pandysautonomia had a significantly reduced density of nerves compared with controls ( 287 nerves/square $\mathrm{mm} \pm 2 \cdot 0$ ). Despite this deficit, acetylcholinesterase-positive nerve fibres were present in the lamina propria of both patients with dysautonomia and, as in controls, appeared particularly numerous adjacent to the epithelium (fig 3).

In specimens from controls and the two patients with dysautonomia, catecholaminecontaining nerves were exceedingly sparse, and in

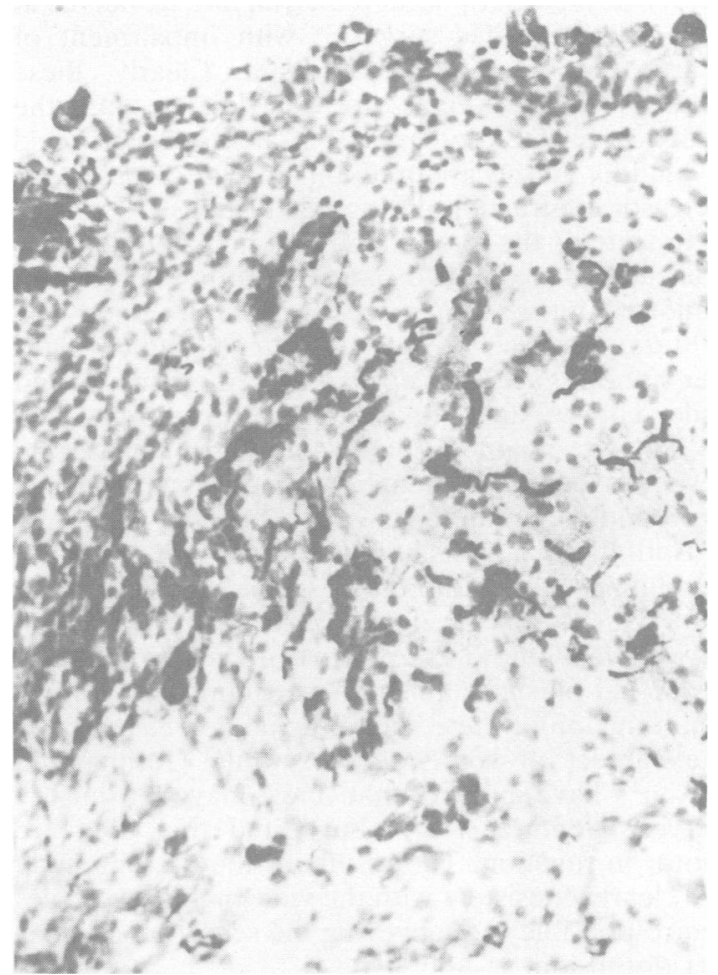

Fig. 3 Bladder biopsy from the patient with cholinergic dysautonomia (case 1). The subepithelial plexus of enzyme positive nerves is preserved in spite of the almost complete absence of similarly staining nerves in the muscularis. $(\times 40)$.

many cases were not observed even after extensive searching of the sections.

\section{Discussion}

The present study serves to define the nature of the bladder dysfunction that occurs in pandysautonomia and cholinergic dysautonomia. The cases are of especial interest because they not only cast light upon the differential roles played by sympathetic and parasympathetic nerves in the lower urinary tract but also provide a means of distinguishing afferent from efferent nerve endings in the bladder.

Urodynamic studies confirmed that the principal defect of bladder function in both patients with dysautonomia was a failure to initiate and sustain an adequate detrusor contraction during attempted micturition. In this context, our finding of an almost complete absence of acetylcholinesterase-positive nerves in Case 1, and a marked reduction in Case 2, is significant: similar depletion in those nerves has also been reported in patients who have suffered 
injury to their peripheral parasympathetic nerves at the time of pelvic surgery ${ }^{25}$ with impairment of detrusor contractility as a result. Clearly, these findings lend weight to the view that the acetylcholinesterase-containing nerves distributed to bladder muscle are predominantly responsible for detrusor contraction during micturition.

In spite of the loss of neurally-mediated detrusor contraction in our two patients, both exhibited an abnormal intravesicular pressure rise in response to $100 \mu \mathrm{g}$ of carbachol. This indicates that their bladder smooth muscle receptor sites remain intact, and indeed are supersensitive, and that the muscle fibres themselves maintain their ability to contract in response to agonist agents, even after many years of profound denervation.

Both these patients had normal sensation of bladder filling, and it therefore seems significant that both patients appeared to have striking preservation of acetylcholinesterase-positive nerves in the suburothelial plexus, similar to that found in controls. The function of these subepithelial nerves has been the subject of some debate: while Gosling and Dixon $^{26}$ have argued that they may be sensory nerves, Uemura et al. ${ }^{27}$ suggested that they are motor in function. The results of the present study are clearly consistent with the view that these nerves are responsible for conveying the sensation of bladder distension.

There are also widely differing opinions concerning the innervation of the striated muscle of the urethral sphincter. Elbadawi and Shenck ${ }^{28}$ have reported that in the dog, this muscle has a triple parasympathic/sympathetic/somatic nerve supply, although Wein et al. ${ }^{24}$ have only been able to demonstrate somatic nerves and motor end plates. The observation that the urethral sphincter electromyography in our two patients revealed entirely normal motor units, and that there was no incontinence, would appear to indicate that, provided somatic nerve function is unimpaired, the striated muscle of the urethral sphincter is able to function normally in spite of a deficit of peripheral autonomic nerve supply.

A further area of controversy is the mechanism by which proximal urethral competence is maintained. Although Barbalias and Blaivas ${ }^{3.3}$ have argued that sympathetic neural activity is essential, Nordling $e t$ al. ${ }^{31}$ maintain that parasympathetic efferent activity is the critical factor. The fact that proximal urethral competence was maintained in our patient with cholinergic dysautonomia, who clearly had complete loss of parasympathetic activity, would appear to support the former view, and implies that the parasympathetic efferent nerves play little or no part in maintaining bladder neck closure.
The cause of the autonomic neuropathy in these and other cases is unknown. An autoimmune aetiology has been suggested on the basis that an experimental autonomic neuropathy may be induced in rabbits by immunisation with human sympathetic tissue. 32 Furthermore, immunofluoresence studies on skin biopsy specimens from a case with pure cholinergic dysautonomia ${ }^{18}$ revealed the presence of IgG antibodies in association with sudomotor postganglionic cholinergic fibres; similar antibodies were absent from control material. It remains to be determined why the autonomic nerves should be selectively involved in these disorders, and why, in the two cases reported here and in others in the literature, recovery was incomplete.

\section{References}

1 Young RR, Ashbury AK, Adams RD, Corbett JL. Pure pandysautonomia with recovery. Trans-American Neurol Assoc 1969;94:355-7.

${ }^{2}$ Young RR, Ashbury AK, Corbett JL, Adams RD. Pure pandysautonomia with recovery: description and discussion of diagnostic criteria. Brain 1975;98:613-36.

${ }^{3}$ Appenzeller O, Kornfield M. Acute pan-dysautonomia: clinical and morphological study. Arch Neurol 1973;29:334-9.

${ }^{4}$ Hopkins AP, Neville B, Bannister R. Autonomic neuropathy of acute onset. Lancet 1974;i:769-71.

5 Yahr MD. Fontera AT. Acute autonomic neuropathy: its occurrence in infectious mononucleosis. Arch Neurol 1978;32:132.

${ }^{6}$ Okada F, Yamashita I, Surva N. Two cases of acute pandysautonomia. Arch Neurol 1975;32:146-51.

${ }^{7}$ Wischer J, Vijayan N, Dreyfus PM. Dysautonomia-its significance in neurological disease. Calif Med $1972 ; 17: 28-37$.

${ }^{8}$ Yee RD, Trese M, Zee DS, Kollanits CR, Cogan DG. Occular manifestations of acute pandysautonomia. Am J Opthalmol 1976;81:740-4.

${ }^{y}$ Low PA, Dyck PJ, Lambert EH et al. Acute panautonomic neuropathy. Ann Neurol 1983; 13:412-7.

${ }^{10}$ Estanol-Vidal B, Ortega RP, Lugo BV, Figarola CG, Viteri MS, Varela ML. Acute autonomic neuropathy. Archives of Investigative Medicine (Mexico) 1979;10:53-64.

"Goulon M, Nouailhat F, Grosbius S, Gajdos PL. Hypotension orthostatique a pouls invariable. Etude hemodynamique d'une neuropathic amyloide et d'une forme idiopathique transitoire. Rev Neurol (Paris) $1971 ; 125: 257-72$.

${ }^{12}$ Colan RV, Sneal OC, Shin JO, Kashlan SJ. Acute autonomic and sensory neuropathy. Ann Neurol 1980;8:441-4.

${ }^{13}$ Fagius J, Westerberg CE, Olsen Y. Acute pandysautonomia and severe sensory deficit with poor recovery. A clinical, neurophysiological and patholog- 
ical case study. J Neurol Neurosurg Psychiatry 1983;46:725-33.

${ }^{14}$ Edelman J, Gubbay SS, Zilko PJ. Acute pandysautonomia due to mixed connective tissue disease. Aust NZ J Med 1981;11:68-70.

is Bannister R. (1983) (Ed.) A Textbook of Clinical Disorders of the Autonomic Nervous System. Oxford, Oxford University Press. 550-3.

10 Thomashevsky AJ, Horwitz SJ, Feingold M. Acute autonomic neuropathy. Neurol (Minneap) 1972; 22: $251-5$.

${ }^{17}$ Anderson O, Lindberg J, Modigh K, Reske-Nielsen E. Subacute dysautonomia with incomplete recovery. Acta Neurol Scand 1972;48:510-9.

${ }^{18}$ Harik SI, Ghandour MH, Farah FS, Afifi AK. Postganglionic cholinergic dysautonomia. Ann Neurol 1977; 1:393-6.

${ }^{19}$ Hopkins IJ, Shield LK, Harris M. subacute cholinergic dysautonomia in childhood. Clin Exp Neurol 1980; 17:147-51.

${ }^{20}$ Bates CP, Whiteside CG, Turner-Warwick RT. Synchronous cine/pressure/flow/cystourethrography with special reference to stress and urge incontinence. $\mathrm{Br} \mathrm{J}$ Urology 1970;42:714-23.

${ }^{21}$ Glahn BE. Neurogenic bladder diagnosed pharmacologically on the basis of denervation supersensitivity. Scand J Urol Nephrol 1970;4:13-24.

${ }^{22}$ Fowler CJ, Kirby RS, Harrison MJG, Milroy EJG, Turner-Warwick RT. Individual motor unit analysis in the diagnosis of disorders of urethral sphincter innervation. J Neurol Neurosurg Psychiatry 1984;47:63741.

${ }^{23}$ Gomori G. (1952). Microscopy histochemistry Principles and Practise. Chicago. University of Chicago. 208-14.
${ }^{24}$ Spriggs TLB, Lever JD, Rees PM, Graham JDP. Controlled formaldehyde catecholamine condensation in cryostat secretions to show adrenergic nerves by fluorescence. Stain Technology 1966;41:323-7.

${ }^{25} \mathrm{Neal} \mathrm{DE}$. The effects on pelvic visceral function of anal sphincter ablating and anal sphincter preserving operations for cancer of the lower part of the rectum and benign colo-rectal disease. Ann $R$ Col Surg (Eng) 1984;66:7-13.

${ }^{26}$ Gosling JA, Dixon JS. Sensory nerves in the mammalian urinary tract. An evaluation using light and electron microscopy. J Anat 1974;117:113-44.

${ }^{27}$ Uemura E, Fletcher TF, Bradley WE. Distribution of lumbar and sacral afferent axons in the submucosa of the cat urinary bladder. Anat Rec 1975;183:579.

${ }^{28}$ Elbadawi A, Schenk E. A new theory of the innervation of the bladder musculature Part 4 . Innervation of the vesico-urethral junction and external urethral sphincter. J Urol 1974;111:613-5.

2" Wein AJ, Benmson GS, Jacobowitz D. Lack of evidence for adrenergic innervation of the external innervation of the external urinary sphincter. $J$ Urology 1979; 121:324-6.

3" Barbalias GA, Blaivas JG. Neurological implications of the pathologically open bladder neck. J Urology 1983; 129: 780-2.

${ }^{3}$ Nordling J, Meyhoff HH, Oleson DP. Cystourethrographic appearance of the bladder and posterior urethra in neuromuscular disorders of the lower urinary tract. Scand J Uro Nephrol 1982;16:115-24.

"2 Appenzeller O, Arnason BG, Adams RD. Experimental autonomic neuropathy: an immunologically induced disorder of reflex vasomotor function. J Neurol Neurosurg Psychiatry 1965;28:510-5. 